\title{
The prognostic value of cadherin switch in bladder cancer
}

\author{
TOBIAS JÄGER ${ }^{1}$, MARKUS BECKER $^{1}$, ANDREAS EISENHARDT ${ }^{2}$, DERYA TILKI $^{3}$, MARTIN TÖTSCH $^{4}$, \\ KURT W. SCHMID ${ }^{4}$, IMRE ROMICS ${ }^{5}$, HERBERT RÜBBEN ${ }^{1}$, SÜLEYMAN ERGÜN ${ }^{6}$ and TIBOR SZARVAS ${ }^{1}$ \\ ${ }^{1}$ Department of Urology, University of Duisburg-Essen, Hufelandstr. 55, 45147 Essen; \\ ${ }^{2}$ Department of Urology, Maria Hilf Hospital, Mönchengladbach, Sandradstrasse 43, 41061 Mönchengladbach; \\ ${ }^{3}$ Department of Urology, University Hospital Grosshadern, Munich, Marchioninistrasse 15, 81377 München; \\ ${ }^{4}$ Institute of Pathology and Neuropathology, University Hospital of Essen, Hufelandstr. 55, 45147 Essen, Germany; \\ ${ }^{5}$ Department of Urology, Semmelweis University, Budapest, Üllöi út 78, 1082 Budapest, Hungary; \\ ${ }^{6}$ Institute of Anatomy, University Hospital of Essen, Hufelandstr. 55, 45147 Essen, Germany
}

Received November 3, 2009; Accepted December 23, 2009

DOI: 10.3892/or_00000741

\begin{abstract}
Loss of E-cadherin expression and gain of Ncadherin expression ('cadherin switch') is shown to be characteristic in epithelial to mesenchymal transition (EMT), a mechanism associated with cancer progression. Furthermore, the prognostic role of P-cadherin in different cancers is controversial. The aim of this study was to evaluate the prognostic significance of 'cadherin switch' on the gene expression level in bladder cancer. Frozen tissue samples of 181 bladder cancer patients and 7 control individuals were analyzed by quantitative real-time PCR. Kaplan-Meier logrank test and Cox univariate and multivariate analysis were performed to assess the prognostic relevance of gene expression of E-, $\mathrm{N}$ - and P-cadherin. Cox univariate analysis revealed that the decrease of E-cadherin and the gain of $\mathrm{N}$ cadherin gene expression are risk factors for cancer-related death $(\mathrm{P}=0.087, \mathrm{P}=0.005$, respectively). Fourteen percent (13/92) of muscle-invasive bladder cancers were N-cadherinnegative. These patients had a significantly poorer prognosis than those with $\mathrm{N}$-cadherin-positive muscle-invasive tumors $(\mathrm{P}=0.024)$. $\mathrm{P}$-cadherin gene expression proved to be a significant independent prognostic factor for both cancerspecific and recurrence-free survival $(\mathrm{P}=0.011, \mathrm{P}=0.036)$. The characteristic 'cadherin switch' between low- and high-stage tumors that we observed and the prognostic significance of E-, $\mathrm{N}$ - and P-cadherin suggests the importance of these markers in bladder cancer progression. The poor patient prognosis in $\mathrm{N}$-cadherin-negative muscle-invasive tumors indicates an alternative, $\mathrm{N}$-cadherin-independent way in bladder cancer progression.
\end{abstract}

Correspondence to: Dr Tibor Szarvas, Department of Urology, University of Duisburg-Essen, Hufelandstr. 55, 45147 Essen, Germany

E-mail: sztibusz@gmail.com

Key words: bladder cancer, cadherin switch, E-cadherin, N-cadherin, P-cadherin, prognosis

\section{Introduction}

Cadherins are a family of calcium-dependent transmembrane glycoproteins that mediate homophilic cell adhesion (1). Different members of the family are found in different locations. While E-cadherin is expressed in all epithelial tissue, $\mathrm{N}$-cadherin is found in neural tissue, fibroblasts, skeletal tissue and endothelial but not epithelial cells $(2,3)$. E-cadherin does have a driving role in maintenance of epithelial differentiation and integrity. In accordance, loss or reduced expression of E-cadherin was found in different cancers (4-6). In urothelial cancer, decreased expression of E-cadherin was associated with increased invasive potential and poor survival (7-10). On the other hand, novel expression of $\mathrm{N}$-cadherin protein was observed in bladder cancer cell lines and tissue samples (11-13). This 'cadherin switch' is a hallmark of epithelial to mesenchymal transition (EMT), a process in which tumor cells lose their epithelial markers and start to express mesenchymal markers. As a feature of aggressive tumors, EMT is characterized by increased motility and invasion and was observed in several human cancers $(14,15)$.

In vitro studies demonstrated that $\mathrm{N}$-cadherin, overexpressed in breast and bladder carcinoma cells enhances their invasive capacity $(16,17)$. Aberrant $\mathrm{N}$-cadherin expression has been associated with a more invasive phenotype in bladder cancer cell lines as well as in breast, prostate and melanoma cells $(11,16)$. Based on these findings, therapeutic strategies targeting $\mathrm{N}$-cadherin have been developed. The first $\mathrm{N}$ cadherin antagonist, ADH1, has recently entered clinical trials (18). Progress in this field may arise demand for molecular methods identifying patients who would most likely benefit from a targeted anti-N-cadherin therapy.

The two publications analyzing the prognostic relevance of $\mathrm{N}$-cadherin protein expression in bladder cancer provided conflicting results $(13,19)$. Interestingly, neither found any correlation between $\mathrm{N}$-cadherin expression and tumor stage and grade.

Much less is known about the function and prognostic relevance of P-cadherin. Reduced P-cadherin expression has shown to be associated with poor prognosis in breast and squamous cell carcinoma $(20,21)$. In contrast, low P-cadherin 
level reported to be a favorable prognostic factor in breast and in endometrial cancer $(22,23)$. The two recent immunohistochemical studies dealing with this issue reported contrary results regarding both expression patterns in different tumor stages and prognostic role of P-cadherin $(24,25)$.

Since the analysis of $\mathrm{N}$ - and P-cadherin expression on protein level provided controversial results and their prognostic relevance on RNA level is unknown, we performed quantitative gene expression analysis on 181 bladder cancer specimens with a long follow-up period by quantitative real-time RT-PCR.

\section{Materials and methods}

Clinical samples. For the present study tumor tissue samples from patients who underwent surgical treatment for bladder cancer in the Department of Urology of the University Hospital Essen between 1990 and 1996 were included. The criteria for enrollment were histopathological diagnosis of urothelial carcinoma of the bladder, no history of other tumor, no chemotherapy before surgery, availability of sufficient tumor tissue and follow-up data. The follow-up data were recorded using both hospital files and information from the responsible urologist/family physician. Initially, all tumors were reclassified according to the WHO classification of urothelial neoplasm of 2004 (26). The seven normal bladder tissue samples we used as controls originated from open enucleations for prostatic adenomas. The Ethics Committee of Essen University Hospital approved the study protocol.

RNA isolation and cDNA synthesis. Prior to RNA isolation, frozen tissue sections from each biopsy were stained with $\mathrm{H} \& \mathrm{E}$ and reviewed by a pathologist. After homogenization by Ultra-Turrax (Janke \& Kunkel, Freiburg) in QIAzol ${ }^{\circledR}$ reagent (Qiagen, Hilden), RNA isolation was performed according to the manufacturer's instructions. Isolated RNA was further purified using the RNeasy $\mathrm{Kit}^{\circledR}$ (Qiagen). Total RNA was quantified using an ultraviolet spectrophotometer (Peqlab ND-1000, Erlangen) at $\mathrm{OD}_{260}$. RNA was reverse transcribed (RT) in a final volume of $20 \mu 1$ containing $200 \mathrm{ng}$ RNA, 1X RT Buffer, $0.5 \mathrm{mM}$ dNTPs, $1.8 \mu \mathrm{M}$ oligo dT, 10 units RNase inhibitor, 40 units Omniscript RTase. The cDNA synthesis was performed at $37^{\circ} \mathrm{C}$ for $60 \mathrm{~min}$.

Taq Man two-step reverse transcription-polymerase chain reaction assay. Quantitative real-time PCR was performed on an ABI Prism ${ }^{\circledR} 7500$ Sequence Detection System (Applied Biosystems). To provide high reproducibility, we used the predeveloped Taq Man ${ }^{\circledR}$ Gene Expression Assay (Applied Biosystems, Foster City, CA). The assay IDs were as follows: E-cadherin; Hs00170423_m1, N-cadherin; Hs00999925_m1, P-cadherin; Hs00169953_m1, TBP; 4333769. The expression levels were related to Universal Human Reference RNA (Stratagene), which was composed of pooled RNA from 10 human cell lines. This allows a reliable lab-to-lab comparison of gene expression data independently of the actually used control sample. We used TBP to normalize our target genes expression. PCR reactions contained $2.5 \mu \mathrm{l}$ cDNA, 1X Taq Man Gene Expression Assay and 1X Taq Man Universal PCR Master Mix (Applied Biosystems), in a $25 \mu 1$ volume.
The thermal cycling conditions were as follows: $95^{\circ} \mathrm{C}$ for $10 \mathrm{~min}$, followed by 40 cycles of $95^{\circ} \mathrm{C}$ for $15 \mathrm{sec}$ and $60^{\circ} \mathrm{C}$ for $1 \mathrm{~min}$. Each sample was tested in duplicate. The threshold cycle $(\mathrm{Ct})$ was determined on the amplification linear area of the target and control genes. The normalized quantity of the target gene was obtained by subtracting $\mathrm{Ct}$ for the internal control (TBP) from the $\mathrm{Ct}$ for the target gene ( $\Delta \mathrm{Ct}$ sample). The same calculation was performed in Human Reference RNA ( $\Delta \mathrm{Ct}$ reference). $\Delta \Delta \mathrm{Ct}$ was subsequently calculated as the difference of these values $(\Delta \Delta \mathrm{Ct}=\Delta \mathrm{Ct}$ sample $-\Delta \mathrm{Ct}$ reference). Finally the result was expressed as $2^{-\Delta \Delta C t}(27)$.

Statistical analysis. The lack of normal distribution of gene expression data (controlled by Shapio-Wilk test) indicated the use of non-parametric two-sided Wilcoxon rank sum test (Mann-Whitney test) for paired group comparisons. Univariate recurrence-free, metastasis-free and disease-specific survival analysis was done using both Kaplan-Meier log-rank test and univariate Cox analysis. For multiple analysis, the Cox proportional hazards regression model was used. Variables with effect on survival in univariate analysis $(\mathrm{P} \leq 0.05)$ were included in the Cox proportional hazards regression models. According to the test of Schoenfeld's residuals, proportional hazards assumption was fulfilled for each variable.

In all tests the P-value of $\leq 0.05$ was considered to be statistically significant. All statistical analyses were done with SPSS software, version 17.0.

The median values of $\mathrm{E}-, \mathrm{N}$ and $\mathrm{P}$-cadherin gene expression values were used as cutoffs for stratification of cases in Kaplan-Meier analysis (335, 0.05, 0.05, respectively). In 54 of 181 bladder tumor specimens $\mathrm{N}$-cadherin real-time PCR analysis yielded no valuable signals, while the other three mRNAs (E-cadherin, P-cadherin and TBP) were detectable. These cases were considered as N-cadherin-negative.

\section{Results}

Clinical background. The main characteristics of patients are given in Table I. The median follow-up period was 34 months with a maximum of 189 months. Seventy-six of 92 patients with muscle-invasive disease were treated by radical cystectomy. In 16 cases transurethral resection (TURB) of the bladder was performed with palliative intent. Eighty-five of 89 patients with non-muscle-invasive bladder cancer were treated by TURB. Seventeen of them were subjected to radical cystectomy because of high-risk tumor (high-grade tumors, CIS or multifocal extensive disease) or disease progression.

Comparison of $E$-, $N$ - and P-cadherin expression between tumor and control samples. We quantified the mRNA expression of $\mathrm{N}$-cadherin in 7 samples of normal bladder epithelium and in 181 samples of tumor tissue. N-cadherin expression was significantly lower $(\mathrm{P}=0.019)$ in tumor than in normal urothelial tissue (Fig. 1). Similarly, markedly (265-fold) decreased P-cadherin levels were detected in tissues of bladder cancer patients $(\mathrm{P}=0.018)$. On the other hand, E-cadherin expression in tumor did not differ significantly from that of non-neoplastic mucosa $(\mathrm{P}=0.146)$. No significant relationships were observed between $\mathrm{E}$-, $\mathrm{N}$ - and $\mathrm{P}$-cadherin mRNA abundance and patient age, gender and smoking habits, 
Table I. Patient characteristics and gene expression.

\begin{tabular}{|c|c|c|c|c|c|c|c|}
\hline & & $\begin{array}{c}\text { E-cadherin } \\
\text { gene exp. values }\end{array}$ & & $\begin{array}{c}\mathrm{N} \text {-cadherin } \\
\text { gene exp. values }\end{array}$ & & $\begin{array}{c}\text { P-cadherin } \\
\text { gene exp. values }\end{array}$ & \\
\hline & $\mathrm{n}$ & Median (range) & $\mathrm{P}$ & Median (range) & $\mathrm{P}$ & Median (range) & $\mathrm{P}$ \\
\hline \multicolumn{8}{|l|}{ Age 66 (34-96) } \\
\hline$\leq 65$ & 82 & $316(1-106463)$ & 0.376 & $0.055(0-8.20)$ & 0.391 & $0.05(0-3350)$ & 0.726 \\
\hline$>65$ & 99 & 375 (0-69033) & & $0.037(0-18.19)$ & & $0.04(0-10226)$ & \\
\hline \multicolumn{8}{|l|}{ Gender } \\
\hline Male & 139 & $362(13-106463)$ & 0.208 & $0.028(0-18.19)$ & 0.086 & $0.040(0-10226)$ & 0.671 \\
\hline Female & 42 & $267(0-3304)$ & & $0.066(0-8.20)$ & & $0.080(0-858)$ & \\
\hline \multicolumn{8}{|l|}{ Stage } \\
\hline $\mathrm{Ta}$ & 57 & $662(13-7913)$ & 0.089 & $0(0-1.68)$ & 0.002 & $0.290(0-10226)$ & 0.038 \\
\hline $\mathrm{T} 1$ & 32 & $371(32-4040)$ & 0.965 & $0.021(0-1.48)$ & 0.374 & $0.015(0-93)$ & 0.477 \\
\hline $\mathrm{T} 2$ & 16 & $316(29-106463)$ & 0.459 & $0.072(0-0.75)$ & 0.290 & $0.050(0-2091)$ & 0.883 \\
\hline $\mathrm{T} 3$ & 54 & $251(24-8749)$ & 0.590 & $0.104(0-18.19)$ & 0.510 & $0.020(0-403)$ & 0.634 \\
\hline $\mathrm{T} 4$ & 22 & $224(0-41332)$ & & $0.109(0-8.20)$ & & $0.060(0-19)$ & \\
\hline Non-invasive & 89 & $510(13-7913)$ & 0.001 & $0.003(0-1.68)$ & $<0.001$ & $0.050(0-10226)$ & 0.297 \\
\hline Invasive & 92 & $249(0-106463)$ & & $0.103(0-18.19)$ & & $0.040(0-2091)$ & \\
\hline \multicolumn{8}{|l|}{ Grade } \\
\hline G1 & 33 & $545(13-7913)$ & 0.905 & $0.001(0-0.40)$ & 0.100 & $0.290(0-10226)$ & 0.288 \\
\hline G2 & 66 & $452(32-5557)$ & 0.001 & $0.018(0-1.68)$ & $<0.001$ & $0.045(0-858)$ & 0.534 \\
\hline G3 & 82 & $233(0-106463)$ & & $0.093(0-18.19)$ & & $0.020(0-2091)$ & \\
\hline Low-grade & 99 & 471 (13-7913) & $<0.001$ & $0.005(0-1.68)$ & $<0.001$ & $0.050(0-10226)$ & 0.258 \\
\hline High-grade & 82 & $233(0-106463)$ & & $0.093(0-18.19)$ & & $0.020(0-2091)$ & \\
\hline Primer & 99 & $392(1-106463)$ & 0.106 & $0.037(0-8.20)$ & 0.425 & $0.060(0-2091)$ & 0.574 \\
\hline Recurrent & 82 & $325(0-84422)$ & & $0.045(0-18.19)$ & & $0.035(0-10226)$ & \\
\hline \multicolumn{8}{|l|}{ Smoking } \\
\hline Yes & 69 & $261(0-5557)$ & 0.225 & $0.057(0-18.19)$ & 0.205 & $0.025(0-858)$ & 0.063 \\
\hline No & 71 & $294(1-41332)$ & & $0.044(0-8.20)$ & & $0.055(0-2091)$ & \\
\hline Unknown & 41 & & & & & & \\
\hline Control & 7 & $115(2-2788)$ & 0.146 & $0.388(0-0.89)$ & 0.019 & $11.920(8-63)$ & 0.018 \\
\hline Tumor & 181 & $339(0-106463)$ & & $0.044(0-18.19)$ & & $0.045(0-10226)$ & \\
\hline
\end{tabular}

P-values recorded are the results from Mann-Whitney tests. All relative P-cadherin gene expression values are $>0$, however values $<0.001$ has been noted as 0 in this table. In $\mathrm{N}$-cadherin-negative cases the relative expression was defined as 0 .

E-cadherin

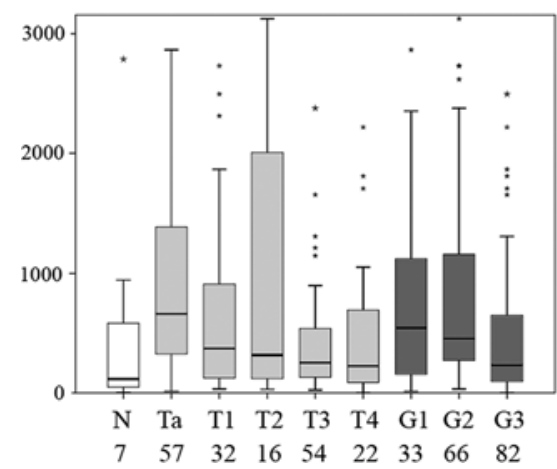

P-cadherin

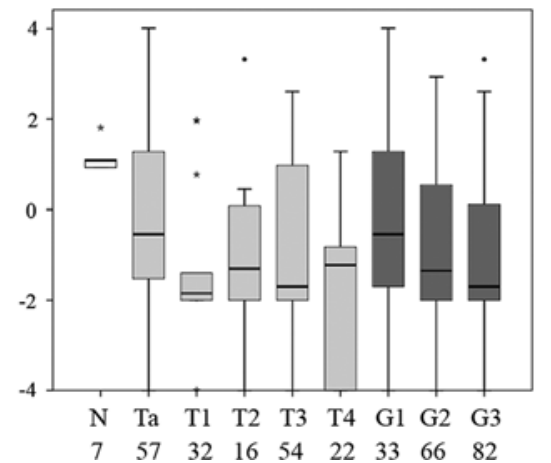

$\mathrm{N}$-cadherin

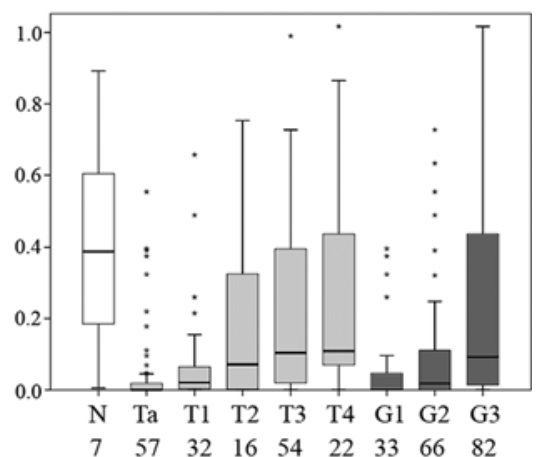

Figure 1. Box-plot representation of E-, N- and P-cadherin gene expression patterns by tumor stage and grade in bladder cancer. Boxes represent the 25th to 75th percentiles; horizontal lines show the median values, stars represent the maximum expression. N, normal bladder epithelium. In case of P-cadherin the y-axis is logarithmically scaled. 
All cases $(\mathrm{Ta}-\mathrm{T} 4)$
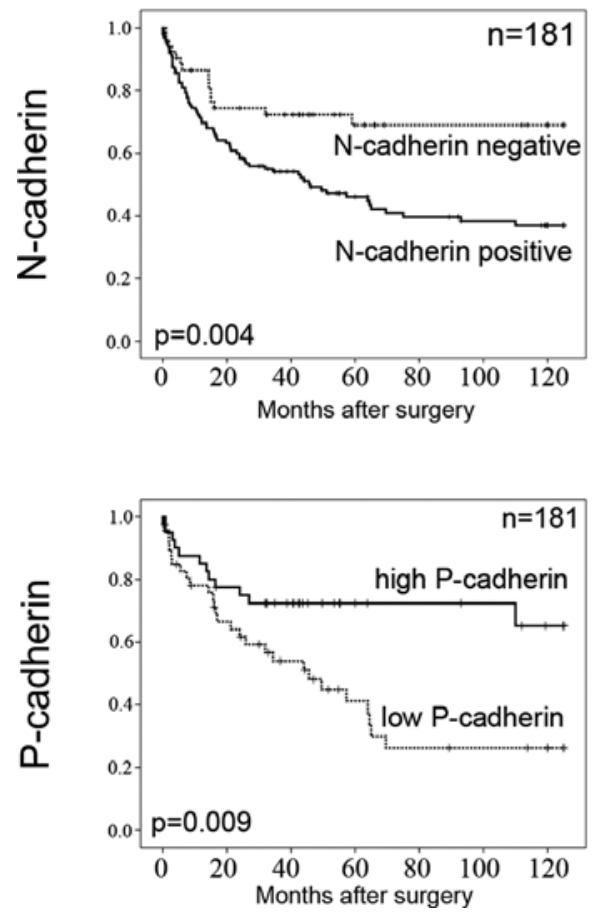

Non-invasive $(\mathrm{Ta} / \mathrm{T} 1)$ cases

Invasive cases (T2-T4)
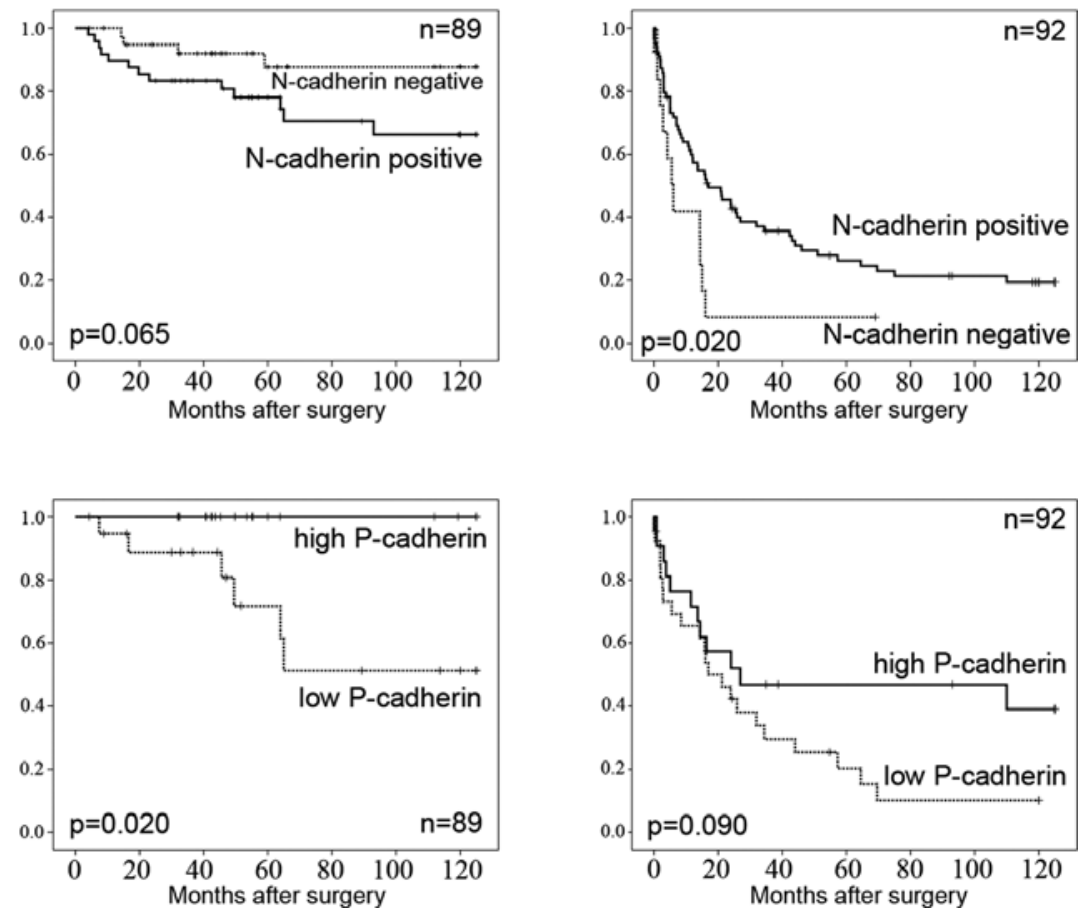

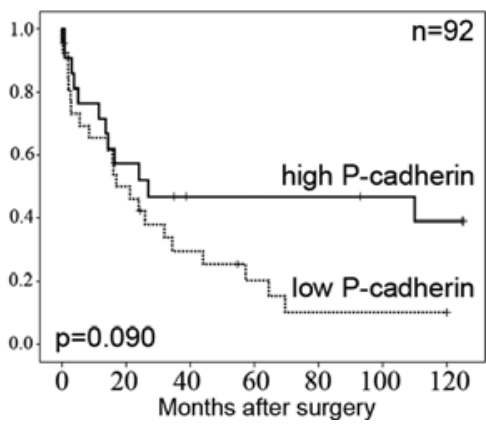

Figure 2. Kaplan-Meier curves of cancer-specific survival. Gene expression values are stratified by N-and P-cadherin. The P-values (log-rank test) in this figure can slightly differ from the P-values of Cox univariate analysis included in Table II.

however P-cadherin expression was higher in smoking patients $(\mathrm{P}=0.063)$ (Table I).

Relationship between gene expression pattern and clinicopathological parameters. Mann-Whitney test revealed significant difference in $\mathrm{N}$-cadherin expression levels between low-stage $(\mathrm{Ta} / \mathrm{T} 1)$ vs. high-stage $(\mathrm{T} 2-\mathrm{T} 4, \mathrm{P}<0.001)$ and between low-grade (G1-G2) vs. high-grade (G3) $(\mathrm{P}<0.001)$ bladder tumors. We found significantly higher levels of Ecadherin expression in superficial $(\mathrm{Ta} / \mathrm{T} 1)$ than in muscleinvasive (T2-T4) bladder cancer stages $(\mathrm{P}=0.001)$. Furthermore, E-cadherin gene expression was significantly lower in grade 3 than in grade 2 cancers $(\mathrm{P}=0.001)$. $\mathrm{P}$-cadherin expression was considerably higher in Ta bladder tumors as in more invasive ones $(\mathrm{P}=0.038)$.

Univariate analysis. Results of univariate analysis of E-, Nand P-cadherin expression and prognostic endpoints (diseasespecific survival, metastasis-free survival and recurrence-free survival) are listed in Table II. Fig. 2 shows the Kaplan-Meier survival curves.

Association of E-, $N$ - and P-cadherin gene expression with disease-specific survival. We identified low E-cadherin gene expression as a borderline significant risk factor for cancerrelated survival $(\mathrm{P}=0.087)$. This, however, was not independent from tumor stage and grade. Furthermore, high expression levels of P-cadherin proved to be an independent favorable prognostic factor for cancer-related survival $(\mathrm{P}=0.011)$. In contrast the presence of $\mathrm{N}$-cadherin expression was associated with higher patient mortality $(\mathrm{P}=0.005)$. Most interestingly, the prognostic impact of $\mathrm{N}$-cadherin expression in patients with non-muscle invasive and invasive disease was opposite. In superficial $(\mathrm{Ta} / \mathrm{T} 1)$ cases $\mathrm{N}$-cadherin gene expression tended to be a risk factor $(\mathrm{P}=0.077)$, while in muscle invasive bladder cancers the lack of $\mathrm{N}$-cadherin gene expression was correlated with strongly reduced patients survival $(\mathrm{P}=0.024)$. (Table II, Fig. 2). In muscle-invasive cases, the average survival time was 11 months in $\mathrm{N}$-cadherin-negative cancers, while it was 37 months in N-cadherin-positive tumors.

Association of $E-, N$ - and P-cadherin expression with metastasis-free survival. Since the formation of metastasis in superficial bladder cancer is a rare event, we preferred to seek correlations with metastasis-free survival only in invasive cases. We did not find any significant correlation between $\mathrm{E}-, \mathrm{N}$ - and $\mathrm{P}$-cadherin expression and metastasis formation $(\mathrm{P}=0.445, \mathrm{P}=0.124, \mathrm{P}=0.496$, respectively).

Association of $E$-, $N$ - and $P$-cadherin with recurrence-free survival. Detection of bladder carcinoma only after $>3$ months after transurethral resection of prior tumor was considered as recurrence. Recurrence-free survival did not correlate with gene expression levels of $\mathrm{E}$ - and $\mathrm{N}$-cadherin $(\mathrm{P}=0.261$, $\mathrm{P}=0.852$ ), but higher $\mathrm{P}$-cadherin expression was found to be associated with early occurrence of disease recurrence $(\mathrm{P}=0.036)$ (Table II).

Multivariate analysis. Multivariate analysis indicated that high $\mathrm{P}$-cadherin expression is an independent favorable prognostic factor of disease-specific survival (HR, 0.391; 95\% CI, 0.196-0.780; $\mathrm{P}=0.008$ ) and an independent risk 
Table II. Cox univariate analysis.

\begin{tabular}{|c|c|c|c|c|c|c|c|c|c|c|}
\hline \multirow[b]{2}{*}{ Variables } & & \multicolumn{3}{|c|}{ Disease-specific survival } & \multicolumn{3}{|c|}{ Metastasis-free survival } & \multicolumn{3}{|c|}{ Recurrence-free survival } \\
\hline & & HR & $95 \% \mathrm{CI}$ & $\mathrm{P}$ & HR & $95 \% \mathrm{CI}$ & $\mathrm{P}$ & HR & $95 \% \mathrm{CI}$ & $\mathrm{P}$ \\
\hline \multicolumn{11}{|l|}{ Age } \\
\hline$\leq 65$ & 82 & ref. & & & ref. & & & ref. & & \\
\hline$>65$ & 99 & 0.958 & $0.628-1.459$ & 0.842 & 0.676 & $0.343-1.330$ & 0.257 & 1.325 & $0.814-2.157$ & 0.258 \\
\hline \multicolumn{11}{|l|}{ Gender } \\
\hline Female & 42 & ref. & & & ref. & & & ref. & & \\
\hline Male & 139 & 0.554 & $0.351-0.873$ & 0.011 & 0.626 & $0.292-1.343$ & 0.229 & 0.637 & $0.367-1.108$ & 0.110 \\
\hline \multicolumn{11}{|l|}{ Stage } \\
\hline Non-invasive & 89 & ref. & & & ref. & & & ref. & & \\
\hline Invasive & 92 & 7.030 & $4.122-11.992$ & $<0.001$ & 7.996 & $3.462-18.466$ & $<0.001$ & 0.461 & $0.252-0.843$ & 0.012 \\
\hline \multicolumn{11}{|l|}{ Grade } \\
\hline Low-grade & 99 & ref. & & & ref. & & & ref. & & \\
\hline High-grade & 82 & 4.884 & $3.059-7.799$ & $<0.001$ & 6.355 & $2.952-13.683$ & $<0.001$ & 0.514 & $0.281-0.940$ & 0.031 \\
\hline \multicolumn{11}{|l|}{ Prior recurrence } \\
\hline Primer & 99 & ref. & & & ref. & & & ref. & & \\
\hline Recurrent & 82 & 1.466 & $0.962-2.236$ & 0.075 & 1.211 & $0.616-2.379$ & 0.597 & 1.309 & $0.814-2.104$ & 0.266 \\
\hline \multicolumn{11}{|l|}{ Smoking } \\
\hline Yes & 69 & ref. & & & ref. & & & ref. & & \\
\hline No & 71 & 0.846 & $0.533-1.341$ & 0.476 & 0.817 & $0.372-1.795$ & 0.615 & 1.296 & $0.730-2.300$ & 0.376 \\
\hline Unknown & 41 & & & & & & & & & \\
\hline \multicolumn{11}{|c|}{ E-cadh. gene expression } \\
\hline Low & 90 & ref. & & & ref. & & & ref. & & \\
\hline High & 91 & 0.690 & $0.452-1.055$ & 0.087 & 0.769 & $0.392-1.509$ & 0.445 & 1.261 & $0.764-2.083$ & 0.364 \\
\hline In non-invasive cases & 89 & & & & & & & & & \\
\hline Low & 31 & ref. & & & ref. & & & ref. & & \\
\hline High & 58 & 0.911 & $0.336-2.469$ & 0.854 & 0.705 & $0.157-3.157$ & 0.647 & 1.229 & $0.695-2.174$ & 0.478 \\
\hline In invasive cases & 92 & & & & & & & & & \\
\hline Low & 59 & ref. & & & ref. & & & ref. & & \\
\hline High & 33 & 1.375 & $0.846-2.236$ & 0.199 & 1.909 & $0.888-4.103$ & 0.098 & 1.064 & $0.355-3.190$ & 0.912 \\
\hline \multicolumn{11}{|c|}{$\mathrm{N}$-cadh. gene expression } \\
\hline Negative & 54 & ref. & & & ref. & & & ref. & & \\
\hline Positive & 127 & 2.221 & $1.273-3.874$ & 0.005 & 1.922 & $0.836-4.415$ & 0.124 & 0.759 & $0.469-1.228$ & 0.261 \\
\hline \multicolumn{11}{|l|}{ In non-invasive cases } \\
\hline Negative & 41 & ref. & & & ref. & & & ref. & & \\
\hline Positive & 48 & 2.750 & $0.897-8.437$ & 0.077 & 1.153 & $0.258-5.153$ & 0.852 & 0.917 & $0.540-1.558$ & 0.749 \\
\hline \multicolumn{11}{|l|}{ In invasive cases } \\
\hline Negative & 13 & ref. & & & ref. & & & ref. & & \\
\hline Positive & 79 & 0.469 & $0.243-0.905$ & 0.024 & 0.442 & $0.150-1.300$ & 0.138 & 0.706 & $0.194-2.575$ & 0.598 \\
\hline \multicolumn{11}{|l|}{ P-cadh. gene expression } \\
\hline Low & 97 & ref. & & & ref. & & & ref. & & \\
\hline High & 84 & 0.416 & $0.211-0.819$ & 0.011 & 0.709 & $0.263-1.910$ & 0.496 & 2.101 & $1.050-4.206$ & 0.036 \\
\hline \multicolumn{11}{|l|}{ In non-invasive cases } \\
\hline Low & 45 & ref. & & & ref. & & & ref. & & \\
\hline High & 44 & 0.017 & $0.000-12.495$ & 0.020 & 0.449 & $0.041-4.967$ & 0.514 & 2.521 & $1.154-5.510$ & 0.020 \\
\hline \multicolumn{11}{|l|}{ In invasive cases } \\
\hline Low & 52 & ref. & & & ref. & & & ref. & & \\
\hline High & 40 & 0.546 & $0.268-1.111$ & 0.095 & 0.787 & $0.261-2.373$ & 0.670 & 1.277 & $0.257-6.345$ & 0.765 \\
\hline
\end{tabular}

HR, hazard ratio; CI, confidence interval and Ref, referent. P-values recorded are the results from Cox analyses. 

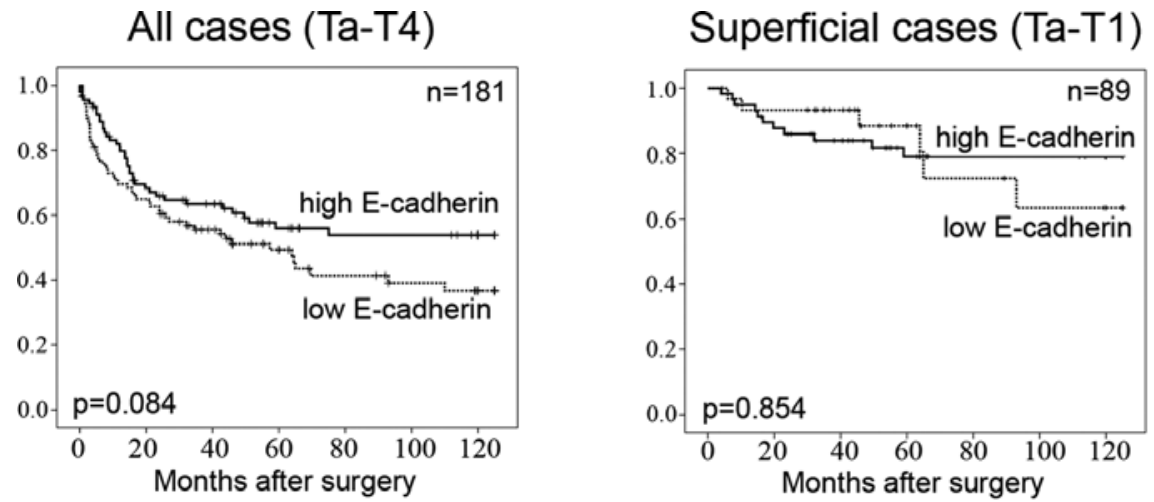

Invasive cases (T2-T4)

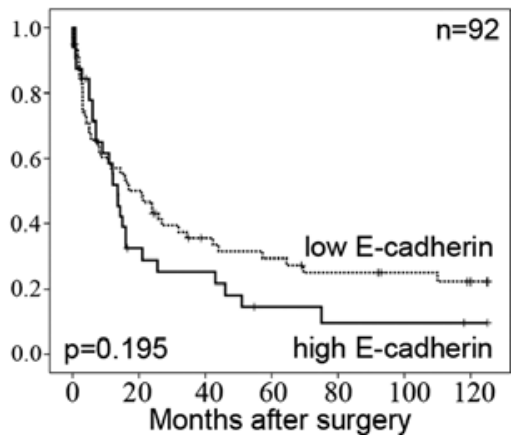

Figure 3. Kaplan-Meier curves of cancer-specific survival. Gene expression values are stratified by E-cadherin. The P-values (log-rank test) in this figure can slightly differ from the P-values of Cox univariate analysis included in Table II.

factor for recurrence-free survival (HR, 2.008; $95 \% \mathrm{CI}$, $0.995-4.053 ; \mathrm{P}=0.052)$ in bladder cancer. Multivariate Cox models are listed in Table III.

\section{Discussion}

In this study, analyzing the gene expression and prognostic value of $\mathrm{E}$ - , $\mathrm{N}$ - and $\mathrm{P}$-cadherin in bladder cancer samples, we observed a characteristic 'cadherin switch' between superficial and invasive bladder cancer, indicated by increasing $\mathrm{N}$ cadherin and decreasing E- and P-cadherin gene expression levels. We demonstrate here for the first time that N-cadherin gene expression strongly correlates with tumor stage and grade in bladder cancer samples. Furthermore, gain of Ncadherin expression proved to be a risk factor in superficial bladder carcinoma. The majority of muscle-invasive bladder cancers of our study (86\%) showed N-cadherin expression; however, in patients with muscle-invasive bladder cancer lack of $\mathrm{N}$-cadherin expression was consistently associated with very poor prognosis. In our opinion, this subgroup represents an alternative way in the progression of bladder cancer.

Loss of E-cadherin expression and novel expression of $\mathrm{N}$-cadherin ('cadherin-switch') is a characteristic feature of epithelial-mesenchymal transition (EMT), a process associated with cancer progression. However, in vitro studies clearly indicated that $\mathrm{N}$-cadherin plays a causal role in the invasion of bladder cancer cells, a correlation between tumor stage and N-cadherin expression on clinical samples could not be substantiated $(12,13,19)$. Furthermore, the prognostic significance of $\mathrm{N}$-cadherin expression in bladder cancer is still unknown.

We observed a strong correlation between $\mathrm{N}$-cadherin gene expression and tumor stage $(\mathrm{P}<0.001)$ and grade $(\mathrm{P}<0.001)$. In contrast Baumgart et al using tissue microarray technique found no correlation between $\mathrm{N}$-cadherin protein expression and tumor stage and grade (13). They and others observed that novel protein expression of $\mathrm{N}$-cadherin shows typically a focal expression pattern; therefore the analysis of small tissue sections (as in TMA analysis) can lead to underrepresentation in the frequency of expression. This could explain the discrepancies in the proportion of N-cadherinpositive tumors which were found using different sampling methods. The lowest occurrence of N-cadherin (8\%) was
Table III. Multivariate Cox regression analysis of histopathological parameters and gene expression levels on diseasespecific, metastasis-free and recurrence-free survival in bladder cancer patients.

\begin{tabular}{lccc}
\hline Variables & HR & $95 \%$ CI & P \\
\hline $\begin{array}{l}\text { Disease-specific survival } \\
\text { Stage }\end{array}$ & & & \\
$\quad$ T2-T4 & 7.009 & $2338-21.552$ & 0.001 \\
Grade & & & \\
$\quad$ High & 1.264 & $0.576-3.085$ & 0.592 \\
$\begin{array}{l}\text { Gender } \\
\text { Male }\end{array}$ & 0.774 & $0.366-1.640$ & 0.504 \\
$\begin{array}{l}\text { E-cadherin expression } \\
\text { High }\end{array}$ & 1.156 & $0.481-2.781$ & 0.746 \\
$\begin{array}{l}\text { N-cadherin expression } \\
\text { Positive }\end{array}$ & 0.556 & $0.187-1.652$ & 0.291 \\
$\begin{array}{l}\text { P-cadherin expression } \\
\text { High }\end{array}$ & 0.391 & $0.196-0.780$ & 0.008 \\
----------------------------------------
\end{tabular}

Recurrence-free survival

Stage

T2-T4

$0.715 \quad 0.235-2.177$

0.555

Grade

High

0.510

$0.152-1.712$

0.275

P-cadherin expression

\begin{tabular}{llll} 
High & 2.008 & $0.995-4.053$ & 0.052 \\
\hline
\end{tabular}

provided by tissue microarray technique (13), while using the same antibody, classical section samples detected positive $\mathrm{N}$-cadherin staining in $39 \%$ of the bladder cancer specimens (12). Since RNA-isolation allows the analysis of a much higher number of tumor cells, the risk of an under-representation is the lowest in this method. According to this interpretation, real-time quantitative RT-PCR, used in the present study, identified the highest proportion of N-cadherin- 
positive tumors $(70 \%)$. This may also explain why none of the immunohistochemical studies have revealed any correlation between tumor stage and $\mathrm{N}$-cadherin level.

In urinary bladder cancer there is a significant risk of understaging after the initial resection, since the surgical resection line often does not reach the layer of tumor invasion or because the biopsy is heat damaged. The significant difference in $\mathrm{N}$-cadherin expression between tumor stage Ta and $\mathrm{T} 1$ we found $(\mathrm{P}=0.002)$ is in accordance with that of Lascombe et al (19). Therefore in our opinion positive Ncadherin gene expression could be an additional criteria for a second TUR in Ta cases. This would result in considerable benefit to patients' management.

Our study revealed significantly higher N-cadherin mRNA level in normal urothelium when compared to bladder cancer tissue, which is in contrast to published observations on protein level $(13,19)$. The only data available regarding $\mathrm{N}$-cadherin mRNA expression in bladder cancer vs. normal urothelium were obtained by gene expression chip analysis and confirm our findings (28). Therefore, we assume that in normal urothelium $\mathrm{N}$-cadherin protein expression is posttranscriptionally regulated.

Similarly to others, we did not observe significant difference in E-cadherin mRNA level between bladder cancer and normal urothelium; we also confirm that E-cadherin mRNA expression decreases with increasing tumor stage (Ta/T1 vs. T2-T4; $\mathrm{P}=0.001)$ and grade $(\mathrm{P}<0.001)(28,29)$. In accordance with previous observations we identified low E-cadherin expression as a predictor of poor patient survival (Table III) $(30,31)$.

High N-cadherin gene expression proved to be a significant prognostic factor for cancer-specific survival $(\mathrm{P}=0.005)$. Patients with superficial $(\mathrm{Ta} / \mathrm{T} 1)$ bladder cancer expressing $\mathrm{N}$-cadherin do have a trend of poorer prognosis $(\mathrm{P}=0.077)$ (Table II). Therefore $\mathrm{N}$-cadherin may be a member of a prognostic panel to predict disease outcome in superficial bladder cancer.

A remarkable finding of this study is the extreme poor prognosis in muscle-invasive bladder cancer cases lacking $\mathrm{N}$-cadherin expression $(\mathrm{P}=0.024)$. Fourteen per cent $(13 / 92)$ of muscle-invasive tumors of the present study proved to be $\mathrm{N}$-cadherin-negative $(2 \times \mathrm{T} 2,8 \times \mathrm{T} 3$ and $3 \times \mathrm{T} 4)$. Twelve of these 13 patients died of bladder cancer within 18 months. The average survival time in this group was 3.5 -fold lower than in $\mathrm{N}$-cadherin expressing muscle-invasive bladder cancer cases (11 vs. 37). Furthermore, E-cadherin gene expression was 2 -fold higher in $\mathrm{N}$-cadherin-negative high-risk group than in $\mathrm{N}$-cadherin-positive invasive cancers, indicating a lack of 'cadherin switch' in these cases. As recently reported by our group using the same tissue samples comparative analysis of gene expression pattern of angiogenic factors, revealed a significant 2-fold higher expression levels of VEGF in 'highrisk' (N-cadherin-negative muscle-invasive) group compared to $\mathrm{N}$-cadherin-positive muscle invasive cancers (32). Therefore, we assume that lack of $\mathrm{N}$-cadherin expression in invasive bladder cancer could identify a more aggressive way of disease progression characterized by the absence of 'cadherin-switch' and higher angiogenic activity.

Little is known about the role of P-cadherin expression in bladder cancer. The two recent studies reported controversial results. Bryan et al found weak immunostaining for P-cadherin in normal urothelium and increased P-cadherin expression in high-stage tumors. They identified P-cadherin as a significant risk factor for cancer-specific survival (24). In contrast Mandeville et al found positive membranous P-cadherin immunostaining in the basal layer of normal urothelium. As in normal bladder urothelium, superficial tumors expressed P-cadherin, whereas $50 \%$ of muscle-invasive cancers were P-cadherin-negative (25). Furthermore, high P-cadherin gene expression proved to be an independent favorable prognostic factor of cancer-related survival (HR, 0.391; 95\% CI, $0.196-0.780 ; \mathrm{P}=0.008)$ and a risk factor of recurrence in superficial cancers after tumor resection $(\mathrm{P}=0.020)$. This is in accordance with the well known fact that superficial bladder tumors often recur, but rarely progress. Based on these findings, we assume an invasion suppressor role for $\mathrm{P}$-cadherin in bladder cancer as it has been recently demonstrated in in vitro experiments on breast cancer cells (33).

In conclusion, analyzing a large number of clinical samples, we observed a characteristic 'cadherin switch' from E- and Pto $\mathrm{N}$-cadherin during the progression of bladder cancer. We assume an invasion suppressor role for E- and P-cadherin and an invasion enhancer function for $\mathrm{N}$-cadherin in urinary bladder cancer.

By comparing gene expression data with a long follow-up period, our study indicates a prognostic significance of a 'cadherin switch' in bladder cancer. $\mathrm{N}$-cadherin expression predicts patient survival in superficial (Ta/T1) bladder cancer. The poor patient prognosis in $\mathrm{N}$-cadherin-negative muscle-invasive tumors suggests an alternative, $\mathrm{N}$-cadherinindependent way in bladder cancer progression. Furthermore, we identified P-cadherin gene expression as an independent predictor of cancer-related survival and tumor recurrence.

In conclusion, changes in expression of different cadherins may help to identify high-risk bladder cancer patients. However, a further prospective study is needed to confirm these results.

\section{Acknowledgements}

We thank Sabine Hertel for help in statistical analysis and Jacqueline Wittschier for excellent technical assistance. Grant support: National Federal Ministry of Education and Research (0313659B).

\section{References}

1. Takeichi M: Cadherin cell adhesion receptors as a morphogenetic regulator. Science 251: 1451-1455, 1991.

2. Matsuyoshi $\mathrm{N}$ and Imamura S: Multiple cadherins are expressed in human fibroblasts. Biochem Biophys Res Commun 235: 355-358, 1997.

3. Salomon D, Ayalon O, Patel-King R, Hynes RO and Geiger B: Extrajunctional distribution of N-cadherin in cultured human endothelial cells. J Cell Sci 102: 7-17, 1992.

4. Giroldi LA and Schalken JA: Decreased expression of the intercellular adhesion molecule E-cadherin in prostate cancer: biological significance and clinical implications. Cancer Metastasis Rev 12: 29-37, 1993

5. Chen HC, Chu RY, Hsu PN, et al: Loss of E-cadherin expression correlates with poor differentiation and invasion into adjacent organs in gastric adenocarcinomas. Cancer Lett 201: 97-106, 2003. 
6. Oka H, Shiozaki H, Kobayashi K, et al: Expression of E-cadherin cell adhesion molecules in human breast cancer tissues and its relationship to metastasis. Cancer Res 53: 1696-1701, 1993.

7. Bringuier PP, Umbas R, Schaafsma HE, Karthaus HF, Debruyne FM and Schalken JA: Decreased E-cadherin immunoreactivity correlates with poor survival in patients with bladder tumors. Cancer Res 53: 3241-3245, 1993.

8. Shimazui T, Schalken JA, Giroldi LA, et al: Prognostic value of cadherin-associated molecules (alpha-, beta-, and gammacatenins and p120cas) in bladder tumors. Cancer Res 56: 4154 4158, 1996.

9. Kashibuchi K, Tomita K, Schalken JA, et al: The prognostic value of E-cadherin, alpha-, beta-, and gamma-catenin in urothelial cancer of the upper urinary tract. Eur Urol 49: 839. 845, 2006.

10. Fromont G, Rouprêt M, Amira N, Sibony M, Vallancien G, Validire $\mathrm{P}$ and Cussenot $\mathrm{O}$ : Tissue microarray analysis of the prognostic value of E-cadherin, Ki67, p53, p27, survivin and MSH2 expression in upper urinary tract transitional cell carcinoma. Eur Urol 48: 764-770, 2005.

11. Giroldi LA, Bringuier PP, Shimazui T, Jansen K and Schalken JA: Changes in cadherin-catenin complexes in the progression of human bladder carcinoma. Int J Cancer 82: 70-76, 1999.

12. Rieger-Christ KM, Cain JW, Braasch JW, et al: Expression of classic cadherins type I in urothelial neoplastic progression. Hum Pathol 32: 18-23, 2001.

13. Baumgart E, Cohen MS, Silva Neto B, et al: Identification and prognostic significance of an epithelial-mesenchymal transition expression profile in human bladder tumors. Clin Cancer Res 13: 1685-1694, 2007.

14. Gravdal K, Halvorsen OJ, Haukaas SA and Akslen LA: A switch from E-cadherin to $\mathrm{N}$-cadherin expression indicates epithelial to mesenchymal transition and is of strong and independent importance for the progress of prostate cancer. Clin Cancer Res 13: 7003-7011, 2007.

15. Christiansen JJ and Rajasekaran AK: Reassessing epithelial to mesenchymal transition as a prerequisite for carcinoma invasion and metastasis. Cancer Res 66: 8319-8326, 2006.

16. Hazan RB, Kang L, Whooley BP and Borgen PI: N-cadherin promotes adhesion between invasive breast cancer cells and the stroma. Cell Adhes Commun 4: 399-411, 1997.

17. Rieger-Christ KM, Lee P, Zagha R, et al: Novel expression of $\mathrm{N}$-cadherin elicits in vitro bladder cell invasion via the Akt signaling pathway. Oncogene 23: 4745-4753, 2004.

18. Kelland L: Drug evaluation: ADH-1, an N-cadherin antagonist targeting cancer vascularization. Curr Opin Mol Ther 9: 86-91 2007.

19. Lascombe I, Clairotte A, Fauconnet S, Bernardini S, Wallerand H, Kantelip B and Bittard H: N-cadherin as a novel prognostic marker of progression in superficial urothelial tumors. Clin Cancer Res 12: 2780-2787, 2006

20. Madhavan M, Srinivas P, Abraham E, Ahmed I, Mathew A, Vijayalekshmi NR and Balaram P: Cadherins as predictive markers of nodal metastasis in breast cancer. Mod Pathol 14: 423-427, 2001
21. Lo Muzio L, Pannone G, Mignogna MD, Staibano S, Mariggiò MA, Rubini C, Procaccini M, Dolci M, Bufo P, De Rosa G and Piattelli A: P-cadherin expression predicts clinical outcome in oral squamous cell carcinomas. Histol Histopathol 19: 1089-1099, 2004

22. Stefansson IM, Salvesen HB and Akslen LA: Prognostic impact of alterations in P-cadherin expression and related cell adhesion markers in endometrial cancer. J Clin Oncol 22: 1242-1252, 2004.

23. Paredes J, Albergaria A, Oliveira JT, Jerónimo C, Milanezi F and Schmitt FC: P-cadherin overexpression is an indicator of clinical outcome in invasive breast carcinomas and is associated with $\mathrm{CDH} 3$ promoter hypomethylation. Clin Cancer Res 11: 5869-5877, 2005

24. Bryan RT, Atherfold PA, Yeo Y, Jones LJ, Harrison RF, Wallace DM and Jankowski JA: Cadherin switching dictates the biology of transitional cell carcinoma of the bladder: ex vivo and in vitro studies. J Pathol 215: 184-194, 2008.

25. Mandeville JA, Silva Neto B, Vanni AJ, et al: P-cadherin as a prognostic indicator and a modulator of migratory behaviour in bladder carcinoma cells. BJU Int 102: 1707-1714, 2008.

26. Eble JN, Epstein JI and Sesterhenn I (eds). Pathology and genetics of tumors of the urinary system and male genital organs. In: World Health Organization Classification Of Tumors. IARCC Press, Lyon, pp89-158, 2004.

27. Livak KJ and Schmittgen TD: Analysis of relative gene expression data using real-time quantitative PCR and the 2(-Delta Delta C(T)) Method. Methods 25: 402-408, 2001

28. Dyrskjøt L, Kruhøffer M, Thykjaer T, Marcussen N, Jensen JL, Møller K and Ørntoft TF: Gene expression in the urinary bladder: a common carcinoma in situ gene expression signature exists disregarding histopathological classification. Cancer Res 64: 4040-4048, 2004

29. Taddei I, Piazzini M, Bartoletti R, Dal Canto M and Sardi I: Molecular alterations of E-cadherin gene: possible role in human bladder carcinogenesis. Int J Mol Med 6: 201-208, 2000.

30. Cai T, Piazzini M, Nesi G, et al: E-cadherin mRNA expression analysis in evaluating the natural history of urothelial bladder cell carcinoma: results from a long-term follow-up study. Oncol Rep 17: 925-930, 2007

31. Popov Z, Gil-Diez de Medina S, Lefrere-Belda MA, et al: Low E-cadherin expression in bladder cancer at the transcriptional and protein level provides prognostic information. Br J Cancer 83: 209-214, 2000

32. Szarvas T, Jäger T, Tötsch M, et al: Angiogenic switch of angiopietins-Tie2 system and its prognostic value in bladder cancer. Clin Cancer Res 14: 8253-8262, 2008

33. Sarrió D, Palacios J, Hergueta-Redondo M, Gómez-López G, Cano A and Moreno-Bueno G: Functional characterization of E- and P-cadherin in invasive breast cancer cells. BMC Cancer 9: 74, 2009. 